\title{
Qualitative Pharmacognostical and Phytochemical Evaluation on Moringa oleifera Lam. Leaf
}

\author{
VE Ida Christi ${ }^{1 *}$, M Khadar Bhatcha ${ }^{1}$, K Suganthi ${ }^{1}$ and N I Blesson Sha \\ Fogarty $^{2}$ \\ ${ }^{1}$ PSG College of Pharmacy, Coimbatore, Tamil Nadu, India \\ ${ }^{2} \mathrm{KMCH}$ Institute of Health Sciences and Research, Coimbatore, India \\ *Corresponding Author: VE Ida Christi, Professor, Department of Pharmacognosy, \\ PSG College of Pharmacy, Coimbatore, Tamil Nadu, India.
}

\section{Received: April 28, 2021}

Published: May 20, 2021

(C) All rights are reserved by VE Ida Christi., et al.

\begin{abstract}
The plant Moringa oleifera Lam. is a small tree otherwise called as horseradish tree or drumstick tree which is one of the pantropical species. It is a most useful plant with highly nutritional value and medicinal properties. This current study is planning to evaluate the pharmacognostical and phytochemical properties of Moringa oleifera Lam leaves. Here the pharmacognostical parameter like Macroscopic, Microscopic nature like cellular structure of the leaf and leaf constant characters were evaluated. Preliminary phytochemical analysis was done by using standard procedure. Preliminary phytochemical screening of the extracts of the acetone, ethyl acetate, petroleum ether, chloroform, methanol and aqueous solvents give the positive report for the presence of alkaloid, carbohydrates, proteins tannins and phytosterol. The column chromatography is used to isolate the phytoconstituents in the methanol extract. A white crystalline compound is isolated in the ratio of petroleum ether: chloroform (60:40, 40:60, 20:80) and it was taken for the structural elucidation and subjected to UV-VIS,IR, NMR and Mass spectral studies. It shows the fraction contains pentadecan1-ol. It may be a precursor or intermediate for the biogenesis for some other compound. Antimicrobial activity of methanol and aqueous extracts of the leaf was screened against Staphylococcus aureus, Bacillus subtilis, Klebsiella aerogenes, Pseudomonas aeruginosa, Aspergillus niger Candida albicans. Both extracts shows antibacterial and fungal activity towards these organisms but it was more in alcohol extract. We finally conclude that this study provides Pharmacognostical, Physiochemical and Phytochemical details of the Moringa oleifera leaves which are useful for the researchers in laying down standardization and pharmacopoeia parameters.
\end{abstract}

Keywords: Moringa oleifera; Phytochemical; Antimicrobial; Standardization; Pharmacognostical

\section{Abbreviations}

UV: Ultra Violet; IR: Infrared; NMR: Nuclear Magnetic Resistance

\section{Introduction}

The plant Moringa oleifera Lam. is a monogeneric family, the Moringaceae. Itis called as "Miracle Tree" and the most widely cul- tivated species allover India and in tropical and subtropical regions [1]. It's the native to the sub-Himalayan tracts of India, Pakistan, Bangladesh and Afghanistan. All parts of the Moringa tree are edible and have long been consumed by humans [2]. Research on Moringa mainly pivoted around its leaves, stem bark, root bark, flowers, fruits and seeds because of their immense nutraceutical potential. 
The leaves are rich in vitamin A and C, are considered useful in scurvy and respiratory ailments [3]. They are rich in protein, minerals, beta-carotene, thiamin, riboflavin, and other vitamins, particularly vitamins $\mathrm{A}$ and $\mathrm{C}$. The Moringa seeds are relatively high yield of $36 \%$ Ben oil [4]. The oil contains: $65.7 \%$ Oleic acids; $9.3 \%$ Palmitic acid; 7.4\% Stearic acid; and 8.6\% Behenic acid. The seeds are good for hypertension, gout, asthma, cancer, and anti-aging. It is also having anti-arthritic activity of anti- inflammatory activity $[5,6]$. Oil extracted from Moringa flowers can also be helpful for arthritic pains and rheumatic and gouty joints [7-9]. Moringa flower is a rich reservoir of bioactive phytochemicals and crude flower extracts showed promising antibacterial, antifungal, anti-larval, antioxidant, anti-inflammatory and anticancer properties [10-12]. Its leaves are also used for hiccups, asthma, gout, backache, rheumatism, kidney stone and skin wounds and sores. The aqueous extract of root of this plant is having anti-inflammatory action and hepatoprotective action [13]. The leaf extract of Moringa is having therapeutic activity towards hyperlipidemia, hypocholesterolemic effect $[14,15]$. The evaluation of various plant products according to their traditional uses and medicinal value based on their therapeutic efficacy leads to the discovery of newer and recent drugs for treating more diseases and for trading. The benefits towards the treatment and prevention of diseases towards various ailments of this plant are very interesting and motivated to precede this present work. The pharmacognostical, phytochemical, antimicrobial studies of this work has been used for documentation purpose.

\section{Materials and Methods}

\section{Plant materials collection and authentication}

The leaf of Moringa oleifera Lam is available locally and was collected in and around Coimbatore. The botanical identity has been authenticated by the Director, Botanical survey of India, Coimbatore, No: BSI/SRC/5/23/2012-13/Tech/496. The voucher specimen has been submitted and preserved in herbarium for future reference.

\section{Processing of plant material}

The plant material (leaf) was collected and shade dried at room temperature and was subjected to size reduction to get course powder of desired particle size. This powdered material was subjected to successive extraction. One kilogram powdered drug was extracted with methanol and water separately by cold maceration method for 7 days. Then the extracts were filtered and solvent were evaporated under reduced pressure in a rotary evaporator to get the dry extract. The yield of the dry extracts were calculated and stored in desiccators and used for further experiments.

\section{Microscopical Evaluation of the plant Leaf}

The required sample leaf was cut and removed from the plant and fixed in FAA (Farmalin-5 ml +Acetic acid -5 ml+ 70\% Ethyl alcohol-90 ml). The standard procedure was followed as per the procedure given by Sass, 1940 [16].

Photographs of different magnifications were taken with NIKON Labphoto2 microscopic Unit. For normal observations bright field was used. For the study of Crystals, Starch grains and lignified cells, Polarized light was employed. Under polarized light they appear bright against dark background. Descriptive terms of the anatomical features are as given in the standard Anatomy books $[17,18]$.

\section{Preliminary phytochemical identification}

The plant material was extracted with different solvents separately prepared and subjected to preliminary phytochemical identification test to identify its chemical constituents by using the standard procedures $[19,20]$.

\section{Fluorescence analysis}

The drug powder was treated with different chemical reagents, acids and alkalies. Then this solutions were make a spot on a TLC plate. The developed colours were observed under UV - Fluorescent light at 254 and $366 \mathrm{~nm}$ [21].

\section{Column chromatography}

Column chromatography was used to separate the compounds. For this purpose $10 \mathrm{gm}$ of methanol extract of the plant was taken and placed in a column (column size $90 \mathrm{~cm} \mathrm{X} 2.5 \mathrm{~cm}$ ), Packed with Silica Gel (100 - 200 mesh) are the adsorbent used to complete separation of the component of the sample and various organic solvents in various proportions were used.

Silica gel was made into homogenous suspension by shaking with petroleum ether (first eluent). The bottom of the column was plugged with little cotton to prevent pass put and then the silica gel suspension was poured into the column, set aside for $10 \mathrm{~min}$ utes and used. Methanol extract of the sample was subjected to column chromatography over silica gel. The column was eluted with 
solvents of increasing polarity. They were Petroleum ether, Chloroform, Ethyl acetate, Acetone, Ethanol. The column was run with organic solvents in various proportions to isolate compounds from the plant extract [22].

\section{Spectral study}

The isolated compound was examined under visible and UV light for proximate analysis. For UV and FTIR spectrophotometer analysis the sample was scanned in the wavelength ranging from 260 - 900 nm using Perkin Elmer Spectrophotometer and the characteristic peaks were detected. FTIR analysis was performed using Perkin Elmer Spectrophotometer system, which was used to detect the characteristic peaks in ranging from $400-4000 \mathrm{~cm}^{-1}$ and their functional groups. The peak values of the UV and FTIR were recorded. NMR 30and MASS spectral studies also performed and recorded. Each and every analysis was repeated twice for the spectrum confirmation [23-25].

\section{Evaluation of antimicrobial activity}

The antimicrobial activity of the test sample (leaf) extracts were carried out by standard disc diffusion method (Kirby Bauer method). The bacterial strains used were Staphylococcus aureus (+ve) (NCIM 2079), Bacillus subtilis (+ve) (NCIM2063), Pseudomonas aeruginosa (-ve) (NCIM 2036), Klebsiella aerogenes (-ve) (NCIM 2098) and fungi Candida albicans (NCIM 3102) and Aspergillus flavus (NCIM105) were obtained from National Chemical Laboratory (NCL), Pune and maintained by periodical sub culturing on Nutrient agar and Sabourad dextrose agar medium for bacteria and fungi respectively. From the culture obtained, using sterilized Pasteur loop, one loop full each of the microorganisms were transferred into the test tubes containing sterile nutrient broth for screening studies. The pH of the above media were maintained at 7.2 , it is then sterilized by autoclaving at $121^{\circ} \mathrm{C}$ at $15 \mathrm{lbs}$ pressure for 15 minutes, in which the nutrient broth was used for sub culturing and MHA (Mueller Hinton Media) media was used for screening studies [26,27].

Nutrient broth with standard modification was prepared and sterilized by autoclaving at $120^{\circ} \mathrm{C}\left(151 \mathrm{~b} / \mathrm{in}^{2}\right)$ about $30 \mathrm{ml}$ of nutrient agar medium was transferred aseptically into every sterilized petriplates to get thickness of 5 to $6 \mathrm{~nm}$. The plate were allowed to solidify and upturned to prevent the condensate declining on the agar surface. The plates were dried at $37^{\circ} \mathrm{C}$ sooner than organisms were inoculated in the plates prepared prior, by dipping sterilize swab in the previously standardized inoculums and spread the organism by shacking the swab all over the surface of the medium. The plates were left at room temperature. Reference standard disc ( $6 \mathrm{~mm}$ diameter) was used as positive antibacterial and antifungal (Ciprofloxacin $5 \mu \mathrm{g}$ /disc for bacteria; Nystatin $100 \mu \mathrm{g} /$ disc for fungi) as control. Each extracts of leaf was reconstituted with solvents and tested at the concentration of $200 \mu \mathrm{g} / \mathrm{ml}, 400 \mu \mathrm{g} / \mathrm{ml}$. The paper discs were impregnated appropriately labeled and evenly spaced sides over the inoculated plates. On incubation the bacteria grow on area of the plate excluding those approximately the inhibitory compound of the plant, which they are sensitive. In the duration of overnight the phytocompound present in the plant extract prevents the development of visible growth which indicates the extract is having antibacterial action. The inhibition was measuring the diameter of the inhibition zone after prior incubation and the experiment was executed two fold and the average determination was recorded. The effect produced by the sample was compared with the effect produced by the positive control (Reference Standard Ciprofloxacin $5 \mu \mathrm{g} /$ disc for bacteria; Nystatin $100 \mu \mathrm{g} /$ disc for fungi). The antimicrobial action was evaluated by measuring the width of inhibition zone [28].

\section{Results and Discussion}

\section{Phramacognostical studies}

The leaves are bipinnate or more commonly tripinnate, up to $45 \mathrm{~cm}$ long, and are alternate and spirally arranged on the twigs. Pinnae and pinnules are opposite; leaflets are 1.2 to $2.0 \mathrm{~cm}$ long and 0.6 to $1.0 \mathrm{~cm}$ wide, the lateral leaflets elliptic, the terminal ones obovate; petioles of lateral leaflets are 1.5 to $2.5 \mathrm{~mm}$ long, those of terminal ones 3 to $6 \mathrm{~mm}$ long. The leaflets are finely hairy, green and almost hairless on the upper surface, paler and hairless beneath, with red-tinged midveins, with entire (not toothed) margins, and are rounded or blunt-pointed at the apex and short-pointed at the base. The twigs are finely hairy and green, becoming brown [29].

In transverse view the leaflet has thin lamina and fairly prominent spindle shaped midrib. The midrib is more convex on the abaxial side than the adaxial side. The midrib is $380 \mu \mathrm{m}$ thick and $500 \mu \mathrm{m}$ wide (Figure 1). The epidermal layer of the adaxial and abaxial sides are prominent thick walled. The adaxial epidermal cells are rectangular to squarish in outline. The abaxial epidermal cells are small circular with small tuber cut out growth on the surface. The ground tissue of the midrib includes thick walled, compa- 
ct parenchyma cells. The vascular strand is tangentially stretched thick and collateral (Figure 3). It includes a few diffuse thick walled Xylem elements and small groups of phloem elements situated on the abaxial side of the vascular strand [30].

Microscopic observation revealed that the leaf provided with the anisocytic type of stomata. Stomata are present only in the lower surface $(33.00 \pm 1.00)$ of the leaf whereas, no stomata were present on the upper surface. The stomata measure about $28.75 \pm$ $1.25 \mu \mathrm{m}$ in length and $22.00 \pm 1.25 \mu \mathrm{m}$ in breadth. Transverse section of the leaf revealed that the epidermal cells consist of straight anticlinal walls (Figure 1). Beneath every upper epidermal cell there are about $3.26 \pm 0.10$ palisade parenchyma cells are present; they are very green and tightly packed. Unicellular trichomes are present on upper surface [31-33]. The leaf constant like stomatal number, stomatal index, vein islet number and termination, and palisade ratio of the Moringa olifera Lam. leaf was studied and recorded the data on given table 1.

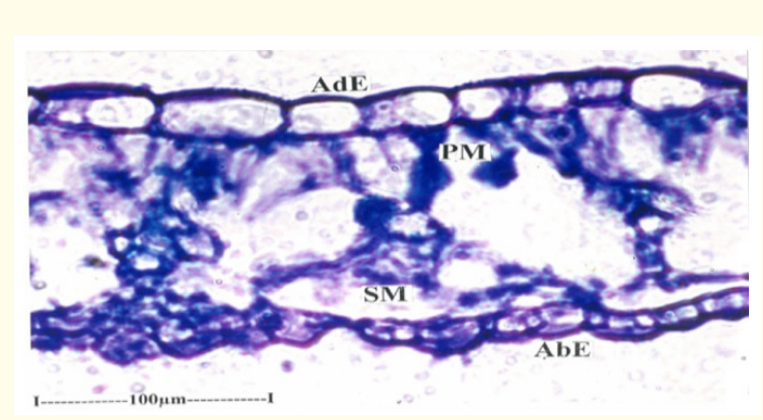

Figure 1: T.S of Moringa oleifera showing leaf lamina.

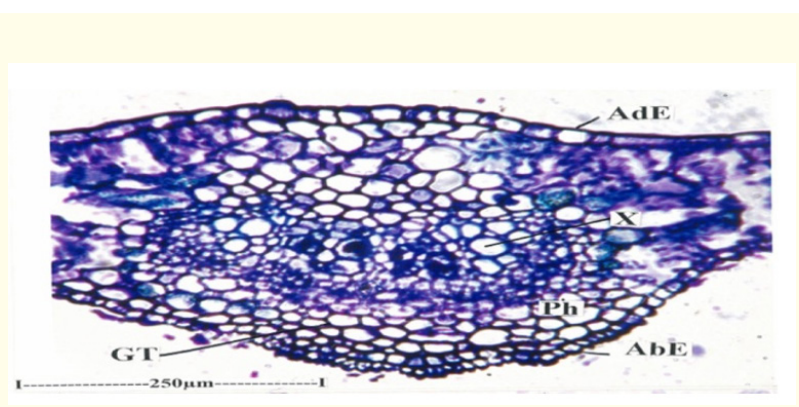

Figure 2: T.S. of Moringa oleifera Lam. leaf showing vascular bundles.

ADS- Adoxial side, ADE - Adoxial Epidermis, AbE- Abaxial Epidermis, GT- Glandular Trichome, MR- MidRib, LA- Lamina.

\begin{tabular}{|l|c|c|}
\hline \multicolumn{1}{|c|}{ Parameters } & Range & Mean \pm SE \\
\hline Palisade ratio & $2.06-3.65$ & $3.26 \pm 0.10$ \\
\hline $\begin{array}{l}\text { Stomata number Upper } \\
\text { surface }\end{array}$ & 0 & 0 \\
\hline $\begin{array}{l}\text { Stomata number lower } \\
\text { surface }\end{array}$ & $31.30-34.69$ & $33.00 \pm 1.00$ \\
\hline $\begin{array}{l}\text { Stomata index upper } \\
\text { surface }\end{array}$ & $13.95-16.56$ & $15.25 \pm 0.20$ \\
\hline $\begin{array}{l}\text { Stomata index lower } \\
\text { surface }\end{array}$ & $26.47-33.52$ & $30.00 \pm 0.50$ \\
\hline Vein islet number & $32.64-43.75$ & $38.20 \pm 3.00$ \\
\hline $\begin{array}{l}\text { Vein termination } \\
\text { number }\end{array}$ & $152.87-180.32$ & $166.60 \pm 4.50$ \\
\hline $\begin{array}{l}\text { Epidermal cells Upper } \\
\text { surface }\end{array}$ & $27.43-30.06$ & $28.75 \pm 1.25$ \\
\hline $\begin{array}{l}\text { Epidermal cells lower } \\
\text { surface }\end{array}$ & $20.02-23.97$ & $22.00 \pm 1.25$ \\
\hline Stomata length & & $184.30 \pm 2.50$ \\
\hline Stomata Breadth & 167.920 .67 & \\
\hline
\end{tabular}

Table 1: Leaf constant of Moringa oleifera Lam.

\section{Phytochemical studies \\ Preliminary phytochemical screening}

The leaf extracts were separately prepared with different solvent system like acetone, ethyl acetate, petroleum ether, chloroform, methanol and water also subjected to chemical tests for the identification of its chemical constituents. The presence of different Phytoconstituents were identified and tabulated in table 2.

\section{Fluorescent analysis}

The leaf powder was treated with different reagents to find out the fluorescent capacity of colour development of drugs at 254 and $366 \mathrm{~nm}$ with different reagents and it was tabulated in table 3.

\section{Spectral studies}

A white crystalline compound was isolated from methanol extract of Moringa olifera in the fractions Petroleum ether : Chloroform in the ratio of (60:40), (40:60), and (20:80) ratio when applied in column chromatography and eluted with different solvents. 


\begin{tabular}{|c|c|c|c|c|c|c|c|}
\hline S.no & Chemical Test & Acetone & $\begin{array}{c}\text { Ethyl } \\
\text { acetate }\end{array}$ & $\begin{array}{c}\text { Petroleum } \\
\text { ether }\end{array}$ & Chloroform & Methanol & Water \\
\hline (1) & Alkaloids & + & + & + & + & + & + \\
\hline (2) & Carbohydrates & + & + & + & + & + & + \\
\hline (3) & Proteins & + & + & + & + & + & + \\
\hline (4) & Free Amino acids & - & - & - & - & - & + \\
\hline (4) & $\begin{array}{c}\text { Tannins and Phenolic } \\
\text { substance }\end{array}$ & + & + & + & + & + & \\
\hline (5) & Phytosterols & + & + & + & + & + & - \\
\hline (6) & Flavanoids & + & + & + & + & + & + \\
\hline (7) & Saponins & + & + & + & + & + & + \\
\hline
\end{tabular}

Table 2: Preliminary phytochemical screening.

\begin{tabular}{|c|c|c|c|}
\hline \multirow{2}{*}{ S. No } & \multirow{2}{*}{ Treatment } & \multicolumn{2}{|c|}{ Fluorescence at } \\
\hline & & $254 \mathrm{~nm}$ & $366 \mathrm{~nm}$ \\
\hline$(1)$ & Powder as such & ---- & --- \\
\hline$(2)$ & Powder + Dilute Nitric acid & Light yellow & Yellow \\
\hline$(3)$ & $\begin{array}{l}\text { Powder+ } 10 \% \text { Sodium } \\
\text { hydroxide }\end{array}$ & Light orange & Orange \\
\hline$(4)$ & $\begin{array}{c}\text { Powder }+1 \mathrm{~N} \text { hydrochloric } \\
\text { acid }\end{array}$ & Yellow & Yellow \\
\hline (5) & Powder $+50 \%$ Nitric acid & Orange & Orange \\
\hline (6) & Powder + Acetic acid & Light brown & $\begin{array}{c}\text { Yellowish } \\
\text { Orange }\end{array}$ \\
\hline (7) & Powder + Picric acid & D yellow & $\begin{array}{c}\text { Yellowish } \\
\text { Orange }\end{array}$ \\
\hline$(8)$ & $\begin{array}{l}\text { Powder }+50 \% \text { Ferric } \\
\text { chloride }\end{array}$ & Orange & Orange \\
\hline (9) & $\begin{array}{c}\text { Powder }+ \text { N/50 Iodine } \\
\text { Solution }\end{array}$ & Dark brown & $\begin{array}{c}\text { Brownish } \\
\text { Red }\end{array}$ \\
\hline$(10)$ & $\begin{array}{c}\text { Powder }+50 \% \text { Sulphuric } \\
\text { acid }\end{array}$ & Light blue & Blue \\
\hline (11) & Powder + Ethanol & Light orange & Orange \\
\hline
\end{tabular}

UV spectrum $[34,35]$

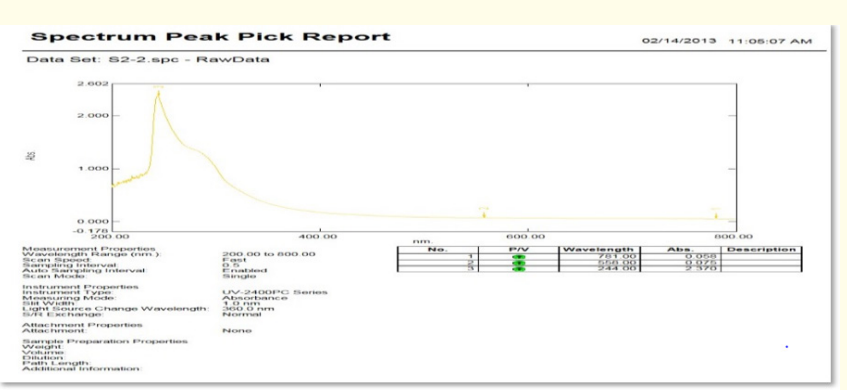

Figure 3: UV spectrum of isolated compound isolated Moringa olifera lam.

Infrared spectrum

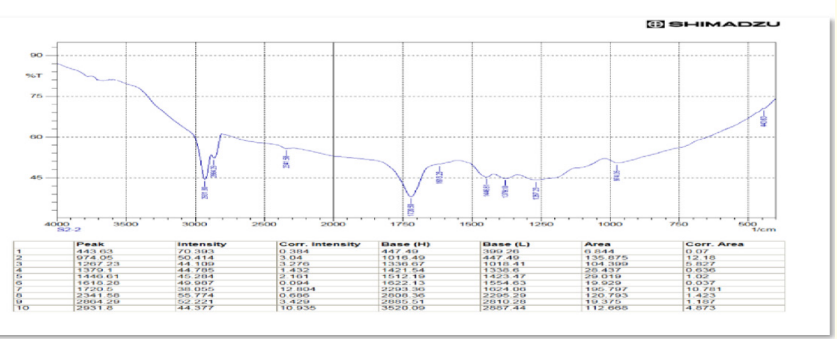

Figure 4: IR spectrum of compound from Moringa oleifera lam. 


\section{NMR spectrum}

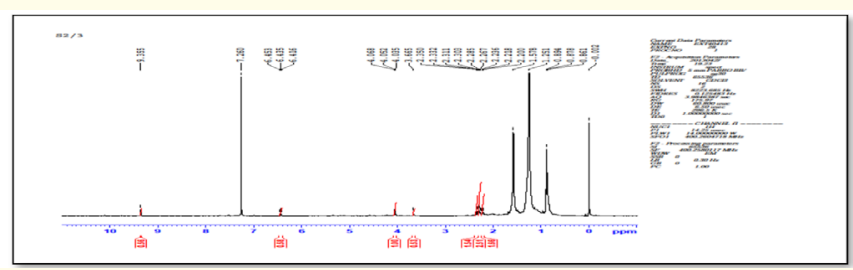

Figure 5: NMR spectrum of compound of from Moringa oleifera Lam.

Mass spectroscopy

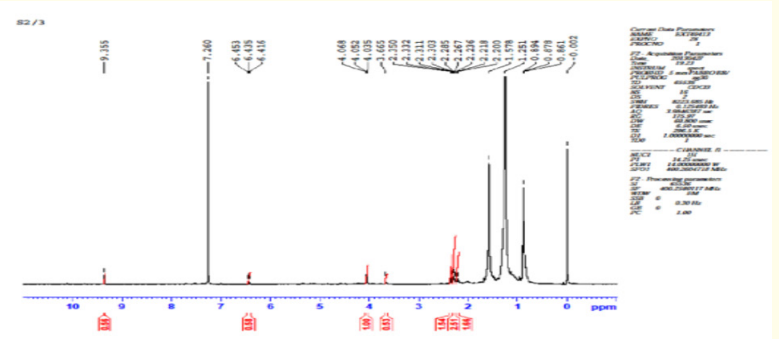

Figure 6: Mass spectrum of compound isolated from Moringa olifera lam.

\section{Spectral description of the compound $[36,37]$}

A compound ( $11.5 \mathrm{mg}$ ) was isolated from the methanolic extract of in the fractions of Petroleum ether: Chloroform (60:40), (40:60) and (20:80). It was White crystalline compound as per the spectral study report it has the singlet at $\delta 0.87$ is owing to methyl group of protons. The broad singlet at $\delta 1.25$ is owing to long chain methylene proton. The triplet at $\delta 4.05$ is owing to $-\mathrm{CH}_{2}-\mathrm{OH}$ group. The singlet at $\delta 2.30$ is owing to $\beta-\mathrm{CH}_{2}$ methylene group to $-\mathrm{OH}$ group. IR absorption band at $3317 \mathrm{~cm}^{-1}$ is owing to $-\mathrm{OH}$ group. Molecular formula $\mathrm{CH}_{3}-\left(\mathrm{CH}_{2}\right) 13-\mathrm{CH}_{2}-\mathrm{OH}$. It may be a penta decanol [38-43].

\section{Proposed structure of the compound}

\section{Antimicrobial studies}

Methanol and water extract of the plant leaf was tested for their antibacterial and antifungal activity. The effect produced by

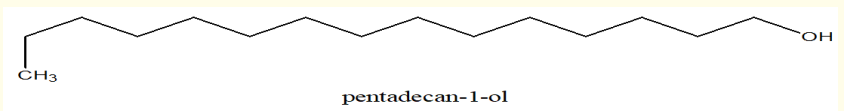

Figure

the sample was compared with the effect produced by the positive control (Reference standard Ciprofloxacin $5 \mu \mathrm{g} /$ disc for bacteria; Nystatin $100 \mu \mathrm{g} /$ disc for fungi). The inhibition of microbial growth was measuring the diameter of the inhibition zone after prior incubation and the experiment was done twice and the average determination was recorded and included [44]. The obtained results are tabulated in table 4.

The aqueous and methanol extract prepared from the selected plant was tested for their antibacterial and antifungal activity. The effect produced by the sample was compared with the effect produced by the positive control (Reference standard Ciprofloxacin 5 $\mu \mathrm{g} /$ disc for bacteria; Nystatin $100 \mu \mathrm{g} /$ disc for fungi). The inhibition of microbial growth was measuring the diameter of the inhibition zone after prior incubation and the experiment was done twice and the average determination was recorded and included Standard-Ciprofloxacin 5 $\mu \mathrm{g}$ /disc for bacteria; Nystatin 100 units/disc for fungi $[44,45]$. The antibacterial and antifungal activity clearly shows that it is a dose dependent. The methanol extract shows better antibacterial activity than the aqueous extract. The extracts shows the activity towards the bacterial organisms in the given order like Staphylococcus aureus $>$ Pseudomonas aeruginosa $>$ Bacillus subtilis > Klebsiella aerogenes. In the dose $200 \mathrm{mg}$ itself shows good activity related to that of the standard drug. The antibacterial activity is better in the dose of $400 \mathrm{mg}$. The extract shows significant effect towards the fungal organisms like Aspergillus niger > Candida albicans in this order and also the activity increases with increasing the quantity. As per the literature different part of this selected plant is having more pharmacological activities anti-inflammatory, analgesic and antipyretic activities [46]. The leaf extracts with methanol and water are having antibacterial and antiviral activity. This study also reveals that the leaf of the selected plant is having antimicrobial activity. 


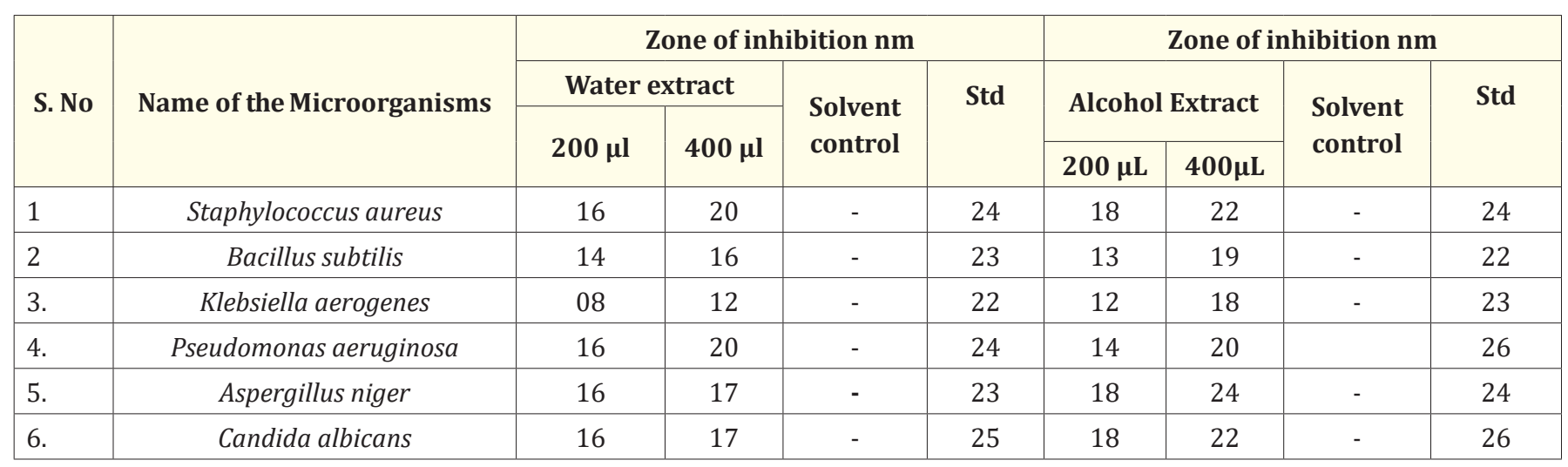

Table 4: The antimicrobial activity of the extracts.

Standard- Ciprofloxacin $5 \mu \mathrm{g} /$ disc for bacteria; Nystatin 100 units/disc for fungi.

\section{Conclusion}

In this study the pharmacognostical parameters like morphological, microscopical and leaf constant were studied and documented. The Pharmacognostical study may be further used for documentation purpose. The preliminary phytochemical study confirms the presence of alkaloids, terpenoids, tannins, flavonoids and phytosterols in the different solvent extract. The methanol extract was subjected for the column chromatography, for the isolation of the active compound and one compound was isolated and its structural elucidation was done by UV, IR, NMR and MASS Spectral studies. The proposed structure of the isolated compound may be penta decanol. It may be the intermediate for the production of secondary metabolite or may be the precursor of the secondary metabolite molecule. The methanol and aqueous extracts shows antimicrobial activity but the methanol extract shows more significant activity than the aqueous extract.

\section{Bibliography}

1. Gamble JS. "Flora of the Presidency of Madras". Vol I, II, III. Botanical Survey of India, Calcutta, India (1935).

2. Agrawal AK., et al. "An ecological analysis of Malin riverain forest of outer Garhwal Himalaya (western Himalaya)". Indian Journal of Ecology 13.1 (1986): 15-21

3. Bodner CC and Gereau RE. "A contribution to Bontoc ethnobotany". Economic Botany 42.3 (1988): 307-369.
4. Chopra R N., et al. "Glossary of Indian Medicinal Plants". Council of Scientific and Industrial Research, New Delhi (1956).

5. Dogra P D., et al. "Vitamin C content in Moringa pod vegetable". Current Science 44.1 (1975).

6. Vishal H Thorat and Deepa T Rangarietal. "Pharmacognostic Account and Phytochemical Studies of Moringa oelifera Lam Department of Pharmacognosy and Phyto chemistry". IJP 5.5 (2018).

7. Bauer R. "Quality criteria and standardization of phytopharmaceuticals: Can acceptable drug standard can be achieved". Journal of Drug Information 32 (1998): 101-110.

8. Vaidya ADB and Devasagayam TPA. "Current status of herbal drugs in India: An overview". Clinical Biochemistry 41.1 (2007): 1-11.

9. Bindu Gopalkrishnan., et al. "Parmacognostical studies of Moringa oleifera Lam". Seeds Journal of Pharmacognosy and Phytochemistry 8.6 (2019).

10. Saurabh Dixit Astha Tripathi., et al. "Medicinal Properties of Moringa oleifera Lam a Review". 3.2 (2016).

11. Sofowora A. "Medicinal plants and Traditional medicines in Africa”. Spect Books Ltd, Ibadan, Nigeria (1993): 289-295. 
12. Newton K Amaglo., et al. "Profiling selected phytochemicals and nutrients in different tissues of the multipurpose tree Moringaoleifera L. grow in Ghana". Food Chemistry 122.4 (2010): 1047-1054.

13. Naznin Ara. "Comparision of Moringa oleifera leaves Extract with Atenolol on Serum triglycerides, Serum Cholesterol, Blood glucose, heart weight, body weight in Adrenalin Induced Rats". Saudi Journal of Biological Sciences 15.2 (2008): 253-258.

14. Gupta M and UK Mazumder. "Anti-epileptic and anti-cancer activity of Moringa oleifera Antioxidant action against antitubercular drugs induced lipid peroxidation in rats". Fitoterapia 70.3 (1997): 244-250.

15. Melesse A., et al. "Evaluating the nutritive values and in vitro de gradability characteristics of leaves, seeds and seedpods from Moringa stenopetala". Journal of the Science of Food and Agriculture 89.2 (2009): 281-287.

16. Sass JE. "Elements of Botanical micro technique”. McGraw Hill Book Co New yark (1940): 222.

17. Easu K. "Anatomy of seed Plants". John Wiley and sons. New York (1979): 550.

18. Johensen DA. "Plant Microtechnique”. Mc Grow Hill Book Co New York. (1940): 523.

19. Kokate CK., et al. "Text book of Pharmacognosy". VI edn, Nirali prakashan, Pune, India (1997).

20. Kandalwal KR. "Practical Pharmacognosy, Techniques and experiments". 13th edition, Nirali prakashan, Pune, India (2005).

21. Ancient Science of Life. 23.3 (2004).

22. Harborne JJ. "Phytochemical Methods: A Guide to Modern Techniques of Plant Analysis". 2nd ed. New York: Chapman and Hall (1984): 85.

23. Duke's. "Phytochemical and Ethnobotanical Databases" (2013).

24. Li-JunNi., et al. "A strategy for evaluating antipyretic efficacy of Chinese herbal medicines based on UV spectra fingerprints". Journal of Ethnopharmacology 124 (2000): 79-86.
25. Cox PA. "Ethnopharmacology and the search for new drugs Bioactive Compounds from Plants Ciba Foundation Symposium, Chichester". John Wiley and Sons 154 (1990): 40.

26. Hosamani PA., et al. "Antimicrobial activity of leaf extract of Andrographis paniculata Wall”. Scientific Reports 1 (2011): 9295.

27. Government of India. "The Pharmacopoeia of India”. New Delhi, $\mathrm{VI}^{\text {th }}$ edition 3 (2010): 2537-2538.

28. Government of India. The Pharmacopoeia of India. New Delhi: Government of India 1 (1996): A105.

29. Henry., et al. "Flora of Tamilnadu, India". Botanical survey of India, Southern circle, Coimbatore, India 3 (1987): 258.

30. Easu K. "Plant Anatomy". John Wiley and sons. New York (1964): 767.

31. Metcalf $\mathrm{C}$ and Randchalk L. "Anatomy of the Dicotyledons". Clarendon Press, Oxford 1,2 (1950) 246.

32. Metcalf C and Randchalk L. "Anatomy of the Dicotyledons". Clarendon Press, Oxford 1,2 (1979): 276.

33. O"Brien., et al. "Polychromatic staining of plants Cell Walls bt toludine blue-o". Protoplasma 59 (1964): 364-373.

34. Ganesan R M and Gurumallesh Prabu. "Synthesis of gold nanoparticles using herbal Acorus calamus rhizome extract and coating on cotton fabric for antibacterial and UV blocking applications". Arabian Journal of Chemistry 12 (2019): 21662174.

35. Benth K Kalaichelvi and SM Dhivya. "Screening of phytoconstituents, UV-VIS Spectrum and FTIR analysis of Micrococcamercurialis (L.)". International Journal of Herbal Medicine 5 (2017): 40-44.

36. Cungui Cheng., et al. "Infrared Spectroscopic studies of Chinese Medicines". Journal Applied Spectroscopy Review 45 (2010): 165-178.

37. Anna Rita., et al. "NMR spectroscopy: a useful tool for characterisation of plant extracts, the case of supercritical CO2 arnica extract". Journal of pharmaceutical and Biomedical Analysis 30 (2002): 321-330. 
38. Anand R., et al. "NMR Spectral Analysis on Root Extract of Zehneriascabra - A Vital Medicinal Climber". Journal of Pharmaceutical Sciences and Research 3 (2011): 1015-1018.

39. Hoan VU., et al. "Direct Screening of Natural Product Extracts Using Mass Spectrometry". Journal of Biomolecular Screening 13 (2008): 927-935.

40. AH Beckett., et al. "Practical pharmaceutical Chemistry". Fourth edition, part Two (1987): 347-355.

41. Benth K., et al. "Screening of phytoconstituents, UV-VIS Spectrum and FTIR analysis of Micrococcamercurialis (L.)". International Journal of Herbal Medicine 5 (2017): 40-44.

42. Li-JunNi., et al. "A strategy for evaluating antipyretic efficacy of Chinese herbal medicines based on UV spectra fingerprints". Journal of Ethnopharmacology 124 (2000): 79-86.

43. Hoan VU., et al. "Direct Screening of Natural Product Extracts Using Mass Spectrometry". Journal of Biomolecular Screening 13 (2008): 927-935.

44. Shihabudeen MH., et al. "Antimicrobial activity and phytochemical analysis of selected Indian folk medicinal plants". International Journal of Pharma Sciences and Research 1 (2010): 430-434.

45. Samy RP and Ignacimuthu S. "Antibacterial activity of some folklore medicinal plants used by tribal in Western Ghats of India". Journal of Ethnopharmacology 69 (2000): 63-71.

46. Osamani PA., et al. "Antimicrobial activity of leaf extract of Andrographispaniculata Wall". Scientific Reports 1 (2011): 92-95.

\section{Volume 5 Issue 6 June 2021}

(C) All rights are reserved by VE Ida Christi., et al. 